\title{
The Lemba - 'angel-stars', ngoma lungundu and ancestors
}

\author{
Prof Magdel le Roux \\ College of Human Sciences. School of Humanities. \\ University of South Africa \\ Email: Lrouxm1@unisa.ac.za \\ Orcid id: https://orchid.org/0000-0002-0770-7303 \\ Doi: https://doi.org/10.46222/pharosjot.102.13
}

\begin{abstract}
Hendel (2004) states that "the remembered past is the material with which biblical Israel constructed its identity as a people, a religion, and a culture. It is a mixture of history, collective memory, folklore, and literary brilliance. In Israel's formative years, these memories circulated orally in the context of family and tribe. Over time they came to be crystallized [mainly] in various written texts" (my insertion). The experiential dimension of religion of ancient Israel and that of the Lemba (the so-called 'Black "Jews" of Southern Africa' and other African tribes) is expressed orally and textually, but also in art. It is in no small part also created by them, as they formulate new or altered conceptions of the sacred past. Guidance by stars, the ancestors and the ngoma lungundu (sacred drum of the ancestors) play a major role in the expression of Lemba and early Israelite religion, culture and art.
\end{abstract}

Keywords: Angel-stars; ngoma lungundu; ancestors; Lemba; early Israel.

\section{Introduction}

The remembered past of the Lemba, the co-called 'Black Jews' of Southern Africa, is indeed a mixture of history, collective memory and folklore which circulated orally in the context of family and tribe. (cf. Hendel, 2004:30) Although it was mainly conveyed around the fire at night, it also became crystallised in books and articles, as well as in various works of art. To a certain extent, a reinforcement and confirmation of the identity of the Lemba have been consolidated when their traditions were written down by some of their leaders and other observers. Except for the short notes and articles of Lemba authors, Mathivha (1992) was the first to have put into writing all possible oral traditions of their culture.

The constructed identity of the Lemba as a people, religion and a culture records that their Israelite ancestors migrated as traders from "the North" (from a place called Sena, whose exact location is unknown ${ }^{1}$ ) to "the South" (into the Arabian Peninsula) in the 7th century BCE, where they established a large community called Sena. Here they met Phoenician and Arabian merchants who introduced them to trading with the Orient and Africa. (Mathivha, 1992:1-7) Folklore of Yemenite Jews not only bears witness to a migration of their ancient forebears from Palestine to Yemen, but also to a group of Jews who left Yemen centuries ago for Africa

\footnotetext{
${ }^{1}$ They did not know the continent, but only knew then that they are "children of Abraham".
} 
and did not return. (Gotein, 1969:226) Parfitt found ruins of an ancient city named Sena, at the end of the wadi Hadramaut, just before the valley turns away towards the sea. $(1992: 5,7)$

Interestingly, Nehemiah 7, in the Old Testament, refers to all the different groups of Israelites who returned to Israel after the Babylonian Exile. Verse 38 records the return of the "children of Sénaä". It is possible that some of the children of Sénaä and other groups escaped the Exile by fleeing to the Arabian Peninsula, such as indicated on inscriptions found in Israel. A Lemba in Soweto once told Parfitt that his ancestors had told him that they had originally come from a place called Sena, "somewhere south of Jericho". (Parfitt 1992:70) In 1999, Dr Wapnick (from Pretoria) made me aware of the fact that a city called "Lemba" exists southeast of Jericho. It is clearly indicated on an ancient map of Moab (in the MacMillan Bible Atlas, 1993, Map 213). Apparently, the name Lemba does not necessarily mean anything (as many wanted to clarify in the past) other than a reference to the place where they came from. A few years later, one of my PhD students, Rabbi Richard Newman, 'discovered' - this time on a map in May's Oxford Bible Atlas - a place called "Senaah". (1984:77) Again, this was southeast of Jericho, just a short distance away from the place called Lemba. The site is identified as Khirbet Libba. Parfitt's informant's 'remembered past' was confirmed.

The historian Josephus also referred to the city of "Lemba". According to him, Judaism was imposed on the cities of ancient Moab (of which Lemba was one) by Alexander Janneus in circa 103-76 BCE (Antiquities XIII:59ff, cited in Zeitlin 1962:332). It is uncertain whether these cities of Lemba and Sena have any link with the Lemba in Southern Africa, but it does give us an educated indication where the Lemba people originally came from. If the Lemba left the cities of Lemba and Sena during the time of Alexander Janneus, it could mean that their oral tradition conveyed from one generation to another is now more than 2300 years old - as confirmed by the maps mentioned above (cf, Le Roux 2009:102-125 in this regard).

The purpose of this article is to emphasise the guidance by stars, the role of the ancestors and the ngoma lungundu in their remembered past and how it relates to a certain extent to the remembered past of the early Israelites in the biblical narratives. ${ }^{2}$ The way in which this remembered past is being depicted in art will also be discussed briefly.

\section{From Africa to the Promised Land and from the Promised Land to Africa}

The proto-Israelites (Israelite tribes) recalled how they escaped Egyptian slavery in Africa (Egypt; Exodus 13-14) and fled to the so-called 'Promised Land'. On their journey through the desert, they were guided by a pillar of fire at night and a column of cloud during the day (Exodus 14:24) - sent by their God (YHWH). These 'objects' showed them where to stop and to set up camp and when to start moving again. They also had a very special object - the Ark of the Covenant -, which was not only perceived as a mobile shrine and a symbol of YHWH's presence (Shekhinah). YHWH spoke from the Ark and the Tabernacle, but the Ark of the Covenant also served as a kind of weapon used against the enemy. It had a specific effect on the enemy (cf. 1 Samuel 6:6), without which victory was not possible. (cf. Albertz, 1994:57; Gottwald, 1985:281; Davies, 1962:222-223; Parfitt, 2008:33). They all went on foot on their journey through the desert to the 'promised land' and the Ark was carried by a sub-clan of the tribe of Levi. (Ginzberg, $1911^{3}$, cited in Hancock, 1993:276) It was not to be touched by anyone, not supposed to touch the ground and it contained some sacred objects of the Israelite tribes (cf. Leviticus 10; 16:1-2) - such as the Ten Commandments. When YHWH

\footnotetext{
${ }^{2}$ The intention is not to provide exegetical analyses of the biblical texts, but only to highlight some interesting similarities.

${ }^{3}$ Not available anymore.
} 
was dissatisfied with the evil practices of this people (for example at Mount Sinai), the wrath of God manifested through the shaking of the earth, the blazing of fire or the roar of thunder. Only Moses and a few devoted persons escaped the wrath of God in the desert (cf. the Book of Numbers).

The remembered journey from Africa to the 'Promised Land' recalled by the Lemba is very similar to that of the proto-Israelites, but just in the opposite direction - from the 'Promised Land' to Africa. They fled from a place called Sena (in the North) to the South. They came by boat to Africa and in Africa they were guided by a star which showed their direction, where they had to set up camp and when to start moving again. (cf. Junod, 1908:277; Möller-Malan, 1953:1-7) In some traditions, the star is referred to as an 'angel-star', but played a similar role. (cf. Steyn, 2019:179) The star eventually stopped at a place now known as Moriah (where the church of Zion was established) in the Limpopo Province (RSA; Le Roux, 2015:123-126). In Africa, the Lemba had to carry an Ark-like object, called the ngoma lungundu (the drum that thunders) for the Vhasendji (most probably the Venda) on their journey southwards into Africa. The ngoma lungundu also served as the symbol of the presence of Mwari, the God of Heaven. (cf. Von Sicard, 1952:175) It was only to be touched and carried by the priestly family for the Lemba (their Buba ancestors), not allowed to touch the ground and contained the sacred objects of the Vhasendji. The sound of the drum had a paralysing effect on their enemies during warfare when smitten. It made them powerless. (Parfitt, 2008:7; Le Roux, 2009:102125)

The main differences between the ngoma lungundu and that of the Ark of the Covenant are the following:

The ngoma lungundu was a drum and the Ark of the Covenant was a chest-like object, the drum belonged to the Vhasendji and the Ark of the Covenant belonged to the Israelites, the drum had special rain-making qualities, while the Ark of the Covenant did not have rain-making qualities and lastly, the Ark was linked to the Covenant with $\mathrm{YHWH}$, while it is uncertain whether the drum was linked to the Covenant.

There are also main differences in the concept of God of the Lemba and that of the early Israelites that should be mentioned:

The Lemba concept of God has three facets: The concept of Mwari or Modimo (in certain areas) the Supreme Being; a Semitic related deity also known as Mwari, Modimo or Jehovah - the God of the Bible and the New Testament notion of Jesus Christ the Son of God and the Holy Spirit. Jesus is seen as the Senior Ancestor. The early Israelites' concept of God included $\mathrm{El}$, and the eternal covenant with their forefathers, Abraham, Isaac and Jacob; YHWH revealed himself to the early Israelites at Mount Sinai and confirmed the convenant between $\mathrm{YHWH}$ and the early Israelites.

The missionary Wangemann was the first to record the tradition of origin of the Lemba in 1868 (:437). He stated that they came by boat to Africa, as traders, on the "back of a tree". (cf. Junod, 1908:277) They most probably made use of the monsoon winds which blow three months of the year in the direction of Africa (from the eastern Hadramaut) and in the opposite direction for another three months of the year.

\section{The role of the ancestors}

In both narratives, as in other, the role of the ancestors should not be underestimated. In early Israel, the names of the ancestors Abraham, Isaac and Jacob featured in most prayers to YHWH. (cf. Le Roux, 2015:129-133) Prayers were ended with the Hebrew word 'amen'. We 
are not sure whether the ancestors played a role as mediators between $\mathrm{YHWH}$ and His people. Their idea of God (YHWH) was, to a certain extent, shaped by influences from other religions, but in principle, they perceived God to be sacred and unique. He was perceived to be the creator, provider, controller but also the One who punished the evil deeds of humankind. YHWH was also known as the God of War. Other gods were recognised, but 'heathen' nations were not tolerated.

He was reminded of his promises to their ancient forebears at all times. Their idea of YHWH was also formed by their own experiences and especially by their ancestors' experiences in the past. The Israelites were therefore, frequently reminded that the head of the family should not forsake the 'cult of the ancestors' (some might have perceived them as gods who could help or hurt them). At important events the early Israelites cited the mighty deeds of YHWH and well as the role of the ancestors in their history (cf. Deuteronomy 26:5b-9). In fact, the Israelites used genealogies to identify their deity and to uncover relationships of people with different names and with different 'tribes' (or clans). Forsaking YHWH's involvement in and rescue activities in the lives of the ancestors, the living would lose their moral right to the land. They believed that the dead lived on in an underworld existence (in Sheol or in sacred places), and the role of the beneficiary or living dead is a daily reminder of their own past and identity. (Le Roux, 2015:138-140) Although offerings to the dead were prohibited and many polemics against these practices existed, they often occurred in early Israel. (Le Roux, 2015:129-133)

Mathivha (President of the Lemba Cultural Association, 1995, Sweet Waters, private communication) once told me: that they worship Mwari, the God of heaven, the God of Abraham and 'just like the ancestors of the Israelites - Abraham, Isaac and Jacob - played a role in Israelite history, so do our ancestors'. The names of their ancestors are also mentioned in their prayers (and recitations) and they play a role as mediators through whom communication takes place (Le Roux, 2015:129-133). Prayer-meetings are held during which they address the ancestors and end their prayers with "amu, amune". Emphasis is placed on Mwari's (God) sacredness and uniqueness and they also perceive him to be the creator, provider and controller who punishes the evil deeds of humankind. In times of war Mwari assisted them. Other gods are accepted, but the Lemba do not mix with the 'heathen' nations.

Their idea of God has also largely been formed by experiences that they had and especially what their forefathers had, but was also determined by influences from other religions in Africa. The head of the family should not forsake the 'cult of the ancestors' (some perceive them to be gods who can help or hurt them). Forsaking the ancestors, the living would also lose their moral right to the land. According to their worldview, the dead live on in an underworld existence (in sacred places) and the role of the living dead is a daily reminder of their own past and identity. As in the case of the early Israelites, offerings are brought to the graveyards. (Le Roux, 2015:138-140) In practice the cult of the ancestors is present in the Lembacommunities.

Before the patriarchal period, the teraphim (household gods) of the proto-Israelites were possibly the mummified heads of the family ancestors which they used in their rituals and which were later replaced with ceramic figures. (cf. 1 Samuel 19:13, 16; Le Roux, 2015) Like the ephod image (of Gideon, cf. Judges 8), the teraphim (cf. Judges 17:5; the Hebrew word for "household gods", the word is in the plural, but singular in meaning) were not associated with divination or prediction. Wherever these 'gods' (teraphim etc) are mentioned in the Old Testament, they are summarily condemned - directly and indirectly. (cf. Le Roux, 2015:138140; Van der Toorn, 1996:225)

Interestingly, today, the Lemba tribe in Southern Africa still has the custom of setting out a small ceramic image together with the spears of the ancestors on a grass mat when they 
consult the ancestors. This ritual is associated in most cases with divination or prediction. (Le Roux, 2015:138-140)

Differences between the cult of the ancestors in the Lemba community and that of the early Israelites are the following:

As mentioned before, some Christians in the Lemba culture even see Jesus as their Senior Ancestor; Mwari's presence is experienced in warfare and those of the ancestors at the graveyard, while YHWH's presence was experienced in warfare and the open shrines and the presence of the Canaanite gods were sought after at their high places (but not those of the ancestors) and to honour one's parents in the Lemba culture is to provide for them after death as well - this interpretation also occurred in some of the early Israelite communities. (Le Roux, 2015:129-140) A trancelike state or communion the ancestors is achieved through specific ritual actions: beer-drinking, the use of secret words, prayers and songs, the calling of the names of the ancestors in a repetitive way and the screaming out in a load voice. In early Israel it is no easy matter to gauge the feelings and sentiments which this 'cult' inspired in the living. The details are no longer known, but the concern for the survival of the names of the ancestors are deeply rooted in the mind of early Israel. The Lemba hold the Gshamo ceremony to celebrate the return of the spirits of the deceased, while no such ceremony was known in the early Israelite community. (Le Roux, 2015:129-140)

\section{The remembered past in art}

Stars or angel-stars, pillars of fire, Ark-like objects and the ancestors are part and parcel of the remembered past of both cultures (early Israelites and the Lemba). As such, they are also depicted in their works of art in one way of another.

Both ancient - such as the Ark on wheels (cut in stone) as discovered in ancient Capernaum - and modern depictions of the Ark are found (as observed during my archaeological visits to Israel). Modern artists' representations of the Ark being carried by the Levites through the desert; being carried around the walls of Jericho and the way it was (most probably) being displayed in the Holy of Holies in the Tabernacle and later in the Temple in Jerusalem, are available today in shops in Israel both in paintings and models.

One also finds expressions of the ngoma lungundu in the remains of ancient examples, such as those preserved by Von Sicard (1952:175) in the museum in Bulawayo. (cf. 1943) photographs taken by Van Heerden of a bigger and smaller ngoma (Van Heerden 1959:3-20) (in the former Venda and northern part of South Africa); photographs taken by anthropologists such as Nettleton (1984, plate V, 18-21; cf. Kirby, 1953:34-39); in private collections in Louis Trichardt (Limpopo Province, RSA) and modern depictions of the ngoma lungundu by Venda artists such as Magoro and Meshak. (Le Roux, 2015:129-140)

\section{Conclusion}

Stars, angel-stars, pillars of fire, ancestors and Ark-like objects have played an important role in the narratives of both the Lemba and the early Israelites. The numerous similarities as well as the meaningful differences between the two communities which are pointed out may be employed for a better understanding of the Old Testament. As an example of this, one may refer to the 'cult of the ancestry'. In the teaching situation, this theme from the learner's own life-world could be used to serve as means to actualise their own pre-knowledge when new tutorial matter is offered, which then deals with the role of the ancestors in the life-world of the early Israelite clans. Many of the questions about the role of the forefathers, the belief in a 
common ancestry and the importance of their entire existence, can possibly elucidate certain parts of the Old Testament. The possibility for example that the ancestors in ancient Israel were seen by some as gods, who were worshipped, and not only as mediums as some thought it to be the case (cf. Van der Toorn, 1996:225 above). In the field one sometimes gets the impression that some of the Lemba respondents want to meliorate this matter, as it seems some of the editors of the Old Testament books tried to do. However, many Lemba refer to their ancestors as 'gods'. The repetition of names of the ancestors at important ceremonies of the Lemba, reminds rather strongly of the creed of the Israelite clans in Deuteronomy 26:5b9, which was cited at important events and in which there was specific reference to the mighty deeds of $\mathrm{YHWH}$, but also to the role of the ancestors in this history. In fact, the Israelites used genealogies to identify their deity and to uncover relationships of people with different names and with different 'tribes' (or clans). These long lists of genealogies serve an important unifying function in the religious culture of early Israel and later, because they lay bare kinship ties hidden under layers of many generations.

With most Lemba in southern Africa, the cult of the ancestors forms part of everyday life along with faith in a 'common ancestry' with early Israelites. In fact, the ancestor cult plays such and extraordinary part in almost every aspect of social, as well as religious life of the Lemba (and other groups in Africa). Belief in a 'common ancestry' and the importance for their entire existence repeatedly emerged.

Without a doubt, oral traditions (in general) were never intended to be written down or to be deposited in writing. By themselves, oral traditions have the functions or the nature of being adaptable and have the potential for repeated innovation. Although this might be true, it might happen that a written work may be 're-oralised', or make the core of a new orally created work, especially when the conveyer has received new information of something he or she wants to add. It is wrong to think that once reading and writing are available, oral culture dies. The oral culture of the Lemba (and that of early Israel) continues even though literacy becomes more common. It is remarkable to see that an oral tradition could survive more than 2000 years in a tribal society.

The Lemba (and the early Israelites) express/ed their desire to find out who they are by telling a story about how they came to be what they are and where they came from. Myth-history is thus a source that provides a sense of identity. Moreover, myth-history is given additional impact when one's identity is expressed in terms of the unseen world - such as being guided by a star, and the ngoma lungundu. (cf, Le Roux, 2015:157). Those narratives or remembered past are not only captured in their oral traditions or written sources, but are also well depicted in both groups' various works of art. The artists are usually also very innovative and often capture new information of something he or she wants to add.

\section{References}

Aharoni, Y. \& Avi-Yonah, M. (1993). The Macmillan Bible Atlas. New York: Macmillan.

Albertz, R. (1994). A History of Israelite Religion in the Old Testament Period. From Beginnings to the End of the Monarchy. Vol I. Kentucky: John Knox.

Davies, G. Henton (1962). Ark of the Covenant. In G.A. Buttrick (Ed). Vol. I of The Interpreter's Dictionary of the Bible. 4 vols. Nashville: Abingdon Press, 222-226.

Goitein, S.D. (1969). "The Jews of Yemen." In A.J. Arberry (Ed). Religion in the Middle East. Three religions in concord and conflict. Vol I. Cambridge: University Press, 226-235. 
Gottwald, N.K. (1985). The Hebrew Bible: a socio-literary introduction. Philadelphia: For-tress.

Hancock, G. (1993). The sign and the seal. A quest for the lost Ark of the Covenant. London: Mandarin.

Hendel, R.S. (2004). Remembering Abraham. Culture, memory and history in the Hebrew Bible. Oxford: Oxford University Press.

Junod, H.A. (1908). The Balemba of the Zoutpansberg (Transvaal). Folklore 19, 276-287.

Kirby, P.R. (1953). The musical instruments of the native races of South Africa. Johannesburg: Witwatersrand University Press.

Le Roux, M. (2015). The Lemba. A lost tribe of Israel in Southern Africa? Revised edition. Pretoria: Unisa Press.

Le Roux, M. (2009). Ngoma lungundu: an African Ark of the Covenant. Old Testament Essays 22, 102-125.

Mathivha, M.E.R. (1992). The Basena/Vamwenye/Balemba. Morester: The Author (Mathivha). May, H.G. (Ed) (1984). Oxford Bible Atlas. New York: OUP.

Möller-Malan, D. (1953). The chair of the Ramapulanas. Cape Town: Central News Agency.

Nettleton, A.C.E. (1984). The traditional figurative wood carving of the Shona and Venda. Vol. I, II \& II. Unpublished Ph. D thesis, Johannesburg: University of the Witwatersrand.

Parfitt, T. ([1992]1997). Journey to the vanished city. The search for a lost tribe of Israel. Second edition. London: Phoenix.

(2008). The lost Ark of the Covenant. The remarkable quest for the legendary Ark. London: HarperCollins.

Steyn, R. (2019). The archangel Michael in Limpopo: The sculptor Jackson Hlungwani and the angel-star of the ngoma lungundu epic. In Ingvild Saelid Gihus, Alexandros Tsakos and Marta Camilla Wright (Eds), The archangel Michael in Africa: history, cult and persona. Great Britain: Bloomsbury, 179-188.

Van der Toorn, K. (1996). Family religion in Babylonia, Syria and Israel. Continuity and change in the forms of religious life. Leiden: Brill.

Van Heerden, P.W. (1959). Die bouvalle van Vendaland. Bantoe 11, 3-20.

Von Sicard, H. (1943). Karangafolkets äldsta Missionshistoria. Stockholm: Svenska Kyrkans. (1952). Ngoma lungundu. Eine africanische Bundeslage. Studia Ethnographica Upsaliensia V. Uppsala: Almquist \& Wiksells Boktrycker.

Zeitlin, S. (1962). The rise and fall of the Judaean state. Vol I. Philadelphia: JPSA. 